\title{
Improved Single Cell Proteome Coverage Using Narrow-Bore Packed NanoLC Columns and Ultrasensitive Mass Spectrometry
}

Yongzheng Cong, ${ }^{\text {I\# }}$ Yiran Liang, ${ }^{\text {I\# }}$ Khatereh Motamedchaboki ${ }^{2}$ Romain Huguet, ${ }^{2}$ Thy Truong, ${ }^{1}$ Rui Zhao, ${ }^{3}$ Yufeng Shen, ${ }^{4}$ Daniel Lopez-Ferrer, ${ }^{2}$ Ying Zhu ${ }^{3}$ and Ryan T. Kelly ${ }^{1,3 *}$

1. Department of Chemistry and Biochemistry, Brigham Young University, Provo, UT, 84602

2. Thermo Fisher Scientific, San Jose, CA, 95134

3. Environmental Molecular Sciences Laboratory, Pacific Northwest National Laboratory, Richland, WA, 99354

4. CoAnn Technologies, LLC, Richland, WA, 99354

\# These author contribute equally to this work

*Email: ryan.kelly@byu.edu 

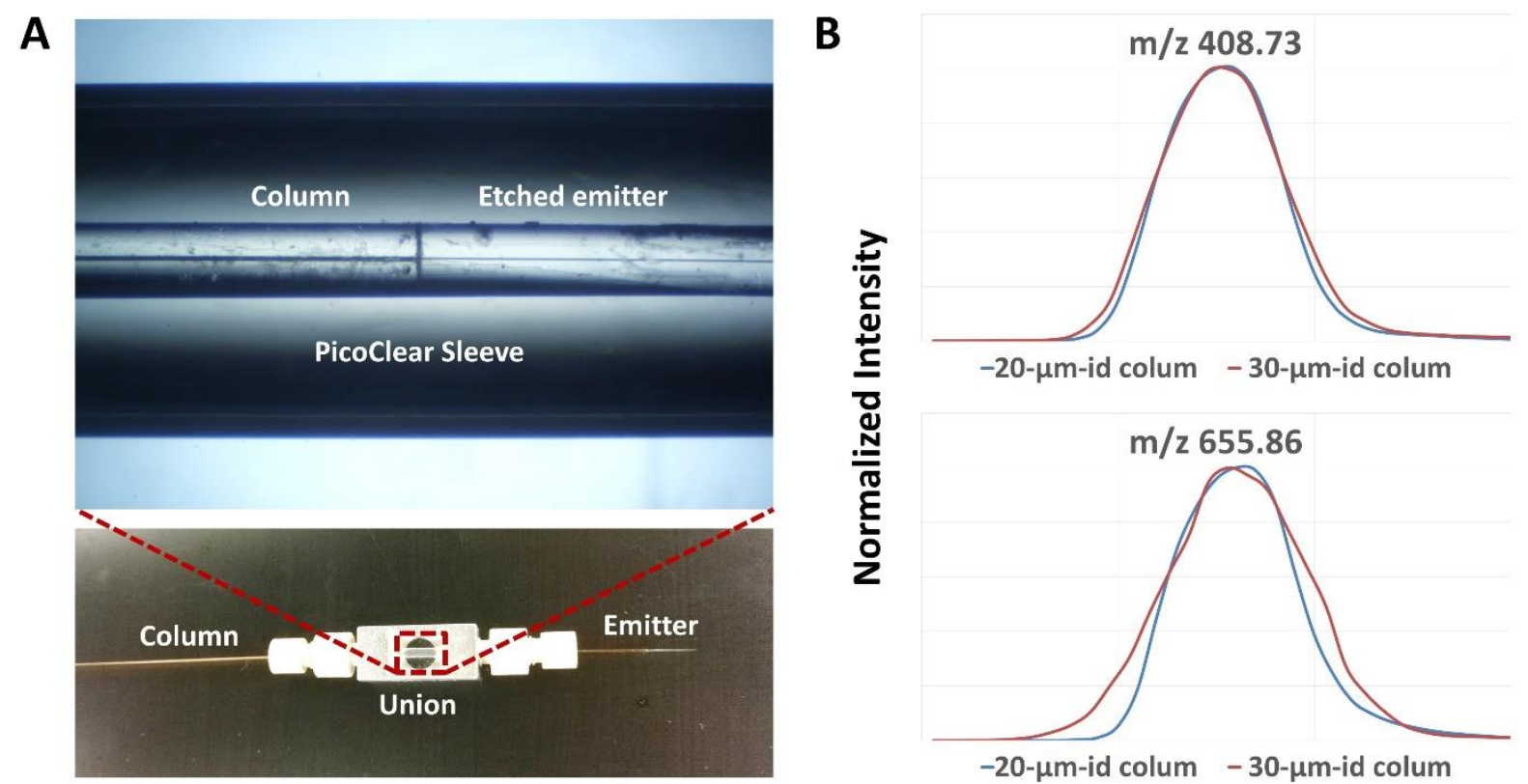

Figure S1. (A) Zero-dead-volume connection between 20- $\mu$ m-i.d. column and 10- $\mu$ m-i.d. etched emitter. Polyimide capillary coating was removed to show a clear connection. (B) Similar peak widths achieved

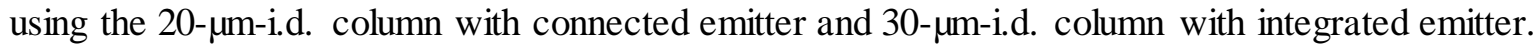


Table S1. Number of Unique peptides and protein groups identified from samples using $20 \mu \mathrm{m}$ i.d. column and Eclipse.

\begin{tabular}{|c|c|c|c|c|c|c|c|c|}
\hline & Identification & $\begin{array}{c}\mathbf{1 0 0} \\
\text { Hela } \\
\text { cells }\end{array}$ & $\begin{array}{c}\mathbf{2 0} \\
\text { Hela } \\
\text { cells }\end{array}$ & $\begin{array}{c}\text { Single } \\
\text { cell 1 }\end{array}$ & $\begin{array}{c}\text { Single } \\
\text { cell 2 }\end{array}$ & $\begin{array}{c}\text { Single } \\
\text { cell 3 }\end{array}$ & $\begin{array}{c}\text { Single } \\
\text { cell 4 } \\
\text { (Large } \\
\text { Hela } \\
\text { cell) }\end{array}$ & Blank \\
\hline Unique & By MS/MS & 9615 & 7261 & 1260 & 1021 & 1551 & 3062 & 12 \\
\hline $\begin{array}{c}\text { peptides } \\
\text { Protein }\end{array}$ & By MS/MS+MBR & 9839 & 7908 & 3657 & 3661 & 3059 & 5865 & 95 \\
\hline groups & By MS/MS+MBR & 1664 & 1478 & 910 & 934 & 778 & 1292 & 88 \\
\hline
\end{tabular}

Raw data files corresponding to Table S1 are available at the ProteomeXchange Consortium via the PRIDE partner repository with the dataset identifier PXD016921. 